\title{
8 Who Takes Part in May Day Marches?
}

\author{
Magnus Wennerhag
}

\section{Introduction}

Since their worldwide spread in 1890, May Day demonstrations have always been connected to a very specific social identity: social class. At the beginning, May Day demonstrations and rallies were thought to display the growing numbers of citizens belonging to the organized parts of the working class and reflect their claims for social and political rights. But what is the social composition of May Day marches more than a hundred years later? Is the annual street manifestation of the labour movement still dominated by workers - or are other social classes and groups also drawn to the streets when trade unions, socialist parties and organizations perform this yearly ritual?

In this chapter I examine which socio-demographic groups take part in contemporary May Day demonstrations in Western Europe. In particular I focus on social class, but also on other relevant social categories such as gender, age and ethnicity and whether they vary between specific types of demonstrations and between the countries in our sample. First, the chapter discusses the socio-demographic profiles of those taking part in such annual events. Are May Day participants more or less representative of the wider population? Do they differ from participants in other types of demonstrations? Second, I interrogate the composition and role of social class in May Day marches, both with regard to the individuals' objective positions in the labour market and their subjective class identifications, and analyse the factors that shape May Day marchers' class identity. Third, I analyse which social and political characteristics most strongly influence individuals' decisions to join a May Day parade.

This chapter's analysis is based on the survey data for individual demonstrators collected within the international research programme 'Caught in the Act of Protest: Contextualizing Contestation' (CCC). In this chapter I analyse the participants in 15 May Day demonstrations in six Western European countries surveyed during the period 2010-2012 (cf. Chapter 7). In order to determine whether participants in May Day demonstrations differ from participants in other types of street protests and marches, I also compare them with data from a sample of 23 additional demonstrations surveyed within 
the CCC project. In order to compare the social composition of the surveyed May Day demonstrations with the general population, I also use data from the European Social Survey and the Swedish SOM Institute's national survey.

The chapter begins with a short overview of the theories relating to the social composition of demonstrations that have become important for understanding contemporary protest participation. This is followed by a discussion about how to conceptualize class at a theoretical level, and how social class is operationalized in the chapter's analysis. In the subsequent methods section, the different types of data and methods used in the analysis are briefly presented. In the following section, I analyse and discuss the chapter's three main topics: (1) the social groups that participate in May Day demonstrations and whether May Day demonstrators differ from participants in other types of demonstrations, (2) the May Day parades' class composition and (3) the social and political factors that influence decisions to join May Day demonstrations.

\section{Earlier Research on Protestors' Social Class and Other Socio-Demographic Characteristics}

\section{The Social 'Normalization' of Protest Participation}

Research on political participation has noted that since the 1960 s citizens in Western democracies have become increasingly inclined to demonstrate in order to give voice to their opinions (see for instance Norris 2002; Norris, Walgrave and Van Aelst 2005). Street protests have become a 'normalized' way for citizens to express their grievances, opinions and political preferences (Van Aelst and Walgrave 2001), alongside their routine participation in general elections.

The research that first analysed the social profiles of demonstrators in a systematic way concluded that protesters were largely young, male and highly educated (March and Kaase 1979). However, surveys undertaken during the 1980s and 1990s showed that differences due to gender and age have decreased, while differences in the level of education persist (Van Aelst and Walgrave 2001, pp. 466-473; see also Verba, Schlozman and Brady 1995). This development has been described as a 'normalization of the protester', in the sense that those taking part in street demonstrations today are increasingly from a cross-section of the general population (Van Aelst and Walgrave 2001). Nevertheless, this research admits that the well-educated still dominate demonstrations.

May Day demonstrations attracted large numbers of citizens to the streets in the late nineteenth and the early twentieth century - decades prior to the post-war development described as a 'normalization' of street protest. Street protests were common during this period when democratic rights were fought for, introduced and consolidated in most Western European countries. Furthermore, these demonstrations were often - or were presumed to have been - dominated by individuals from the working class. ${ }^{1}$ The social composition of the early May Day marches thus differs from that characterizing the street protests that became more common in the 1960s and which have instead been regarded as dominated by the highly educated middle class. In the analysis that follows the aim is to determine whether contemporary May Day demonstrations reflect the social composition of the general population to a higher or lesser degree than other types of demonstrations, in particular those staged by the presumably middle-class-dominated new social movements.

Earlier analyses of protest participation have typically used educational level as a proxy for social class. Even though the individual's level of education is an important determinant of her or his social class, in that it qualifies the individual for specific positions in a hierarchically structured labour market, analyses of protest participation have rarely studied participants' social class according to more refined class concepts. This lacuna exists for both the 'objective' side of class, i.e. the individual's position in the labour market, and the 'subjective' side of class, i.e. the individual's own sense of belonging to a specific (or no) social class.

Rare examples can be found of research on the class profile of the new social movements; movements that have often been associated with the increase in street protests since the 1960s. These movements have often been regarded as expressions of 'middle-class radicalism' (e.g. Eder 1995), although in Kriesi (1989) participation in new social movements is analysed with more refined class categories (on the basis of a Dutch general population survey). Kriesi's study shows that e.g. the environmental and women's movements attracted middle-class individuals to a greater degree than individuals from the working class (even though it was primarily specific parts of the middle class that became involved in these movements).

When comparing the labour movement's contemporary May Day demonstrations with the protests of the so-called new social movements, it is important to remember that since the 1960s the 'old' labour movements have been more or less influenced by, and sometimes even closely intertwined with, the 'new' movements. On the one hand, many of the smaller radical left-wing trade unions and activist networks that today stage or take part in May Day demonstrations have emerged from the 'new social movements' and the 1960s 'new left', as well as from more recent mobilization waves during the 1990s and 2000s (Andretta and Reiter 2009). Furthermore, the left-socialist/ post-communist parties staging May Day parades are often connected with various new social movements, and in addition to more traditional workers' issues also include feminist, peace, environmental and LGBT matters on their agendas (e.g. March 2011, and Chapter 7). On the other hand, only in recent decades have the major social democratic, socialist and post-communist trade unions begun to seek allies among the 'new' movements, for instance during the mobilization of the global justice movement of the 2000 s, and move cautiously in the direction of 'social movement unionism' (see e.g. Waterman 2001; Peterson, Wahlström and Wennerhag 2012). 
Due to these different paths of development within the labour movement, the 15 May Day demonstrations included in the study are first analysed separately and then again in terms to belonging to three major groups. The first group consists of the marches staged by the major trade union confederations and/or a social democratic or socialist party. In the second group the demonstrations have been organized by smaller radical left-wing trade unions and/or radical left parties and activist networks. The third group includes the few cases where a broader coalition consisting of major trade unions and radical left organizations have mobilized the march. This analytical division allows for a critical examination of whether the different paths of development within the labour movement imply that different types of May Day demonstrations mobilize different socio-demographic groups and classes.

\section{Social Class and Political Action}

How, then, can social class be measured in contemporary society? Many of today's most influential methods for measuring social class draw inspiration from Weber's class concept and focus on the individual's employment situation. In contrast to Marx's more relational conceptualization of class as the consequence of the conflict between the owners of the means of production (the capitalists, i.e. the employers) and the owners of labour power (the proletariat, i.e. the employed), Weber (1922/1978, p. 928) saw class as a 'market situation'. For Weber, the common situation of specific groups in the labour market brought different classes into existence. Weber perceived education and other forms of merit as mechanisms that gave access to, or created exclusion from, specific positions in the labour market, and thereby also a range of social opportunities connected to these positions (e.g. Crompton 2010; Wright 2009). In practice, this meant that when studying class Weber understood the main dividing line to be between the different working conditions and opportunities of the working and middle classes. Subsequently, he subdivided the entire class of wage labourers that Marx had seen as potentially united by their common interests vis-à-vis the employers.

This Weberian class concept is the point of departure for Goldthorpe's class scheme, which was first used empirically in the 1970s (and is often referred to as the Eriksson-Goldthorpe-Portocarero, or EGP, scheme) (Crompton 2010). Here, class positions are defined on the basis of employment relations. In the EGP scheme, a basic distinction between employers, self-employed and employees is combined with a further distinction between different forms of employment contracts. The category of employees - which comprises the vast majority of people in developed countries - is subdivided into two ideal contract types: the service contract and the labour contract. According to Goldthorpe, the latter implies easily monitored work with a low degree of required skills and expertise, while the opposite is true for the service contract (Goldthorpe 2000, p. 208).
In Oesch's (2006a, 2006b) more recent and modified version of the EGP scheme, three contemporary labour market trends in developed countries are taken into account. These are the shift from production to service, women's increased participation in paid employment and rising educational levels (Oesch 2006a, p. 27). According to Oesch, the expanding middle class resulting from these trends cannot be properly dealt with by the EGP scheme, and he therefore introduces a horizontal distinction between different work logics (whereas EGP has only a single hierarchical dimension between the service and labour contract). Oesch identifies three work logics: the organizational, the technical and the interpersonal. The self-employed and employers are included in a fourth, independent, work logic (Oesch 2006a, p. 64). The resulting class scheme consists of 17 classes, which can be collapsed into an 8-class version.

In my analysis I have chosen to collapse the original 17 classes into a 9-class scheme (see Table 8.1; see also Hylmö and Wennerhag, 2015). Compared to Oesch's 8-class model, the two 'independent work logic' classes of large employers (with ten or more employees) and self-employed professionals are not collapsed into one combined class. This change is motivated by my analytical aims. As discussed by Peterson in Chapter 7, today's labour market is often described as characterized by growing insecurity. Under such conditions, self-employment increasingly becomes a necessary alternative to regular employment. The market position of, for example, freelance journalists differs significantly from that of large employers, which motivates separating the two classes in the analyses.

If class position is in principal perceived as a position in the occupational structure, how do categorizations of class then relate to political participation? For example, Oesch has used his class scheme to study participation in general elections and party preferences. His studies show that socio-cultural professionals, whose employment is structured by an interpersonal work logic (e.g. teachers, social workers, medical doctors), show a greater support for libertarian left parties than professionals subjected to a technical work logic (e.g. mechanical engineers, computer professionals, architects), who instead more often support conservative centre-right parties (Oesch 2008a, 2008b).

Other scholars have claimed that political preferences are primarily shaped by class identity, and not the individual's position in the labour market (Cigéhn and Johansson 1997). From this perspective, one's subjective sense of belonging to a specific class is not necessarily aligned with one's position in the labour market (Cigéhn, Johansson and Karlsson 2001; Crompton 2010). In this approach the 'subjective' aspect of social class is focused, but only the individual's recognition of different social classes and belonging to one of these, i.e. class identity (which is not to be confused with class consciousness, which implies a belief that one's own class has different and opposite interests vis-à-vis other classes).

For analyses of citizens' political preferences and voting behaviour, different approaches to social class have corroborated that both objective and subjective class have significance. Whether these two conceptualizations of class also contribute to our understanding of May Day participation will now be interrogated. 


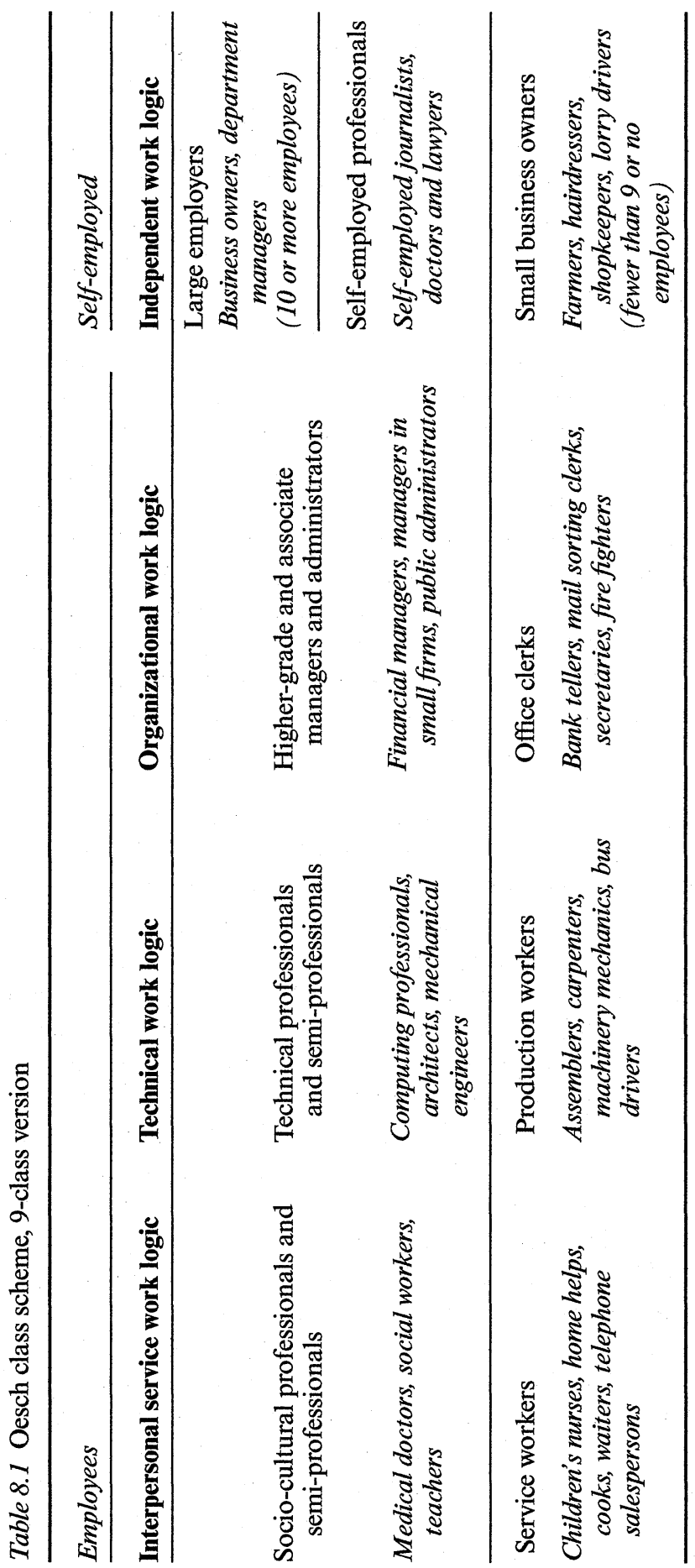

\section{Methods and Data}

The data used in this chapter primarily derives from 2,336 respondents to protest surveys from 15 May Day demonstrations in six Western European countries between 1 May 2010 and 1 May 2012. In order to compare May Day demonstrations with other types of demonstrations, 23 additional protests surveyed within the CCC project have also been included: ten trade union demonstrations, eight environmental protests and five Pride parades, where the two latter types of demonstration are regarded as 'new' social movement mobilizations. More information about the demonstrations surveyed within the CCC project and a more elaborate description of the project's standardized sampling procedure can be found in the Appendix.

In order to compare May Day participants with the general population I have used data for the relevant countries from the 2010 European Social Survey Round 5 (ESS5). ${ }^{2}$ Since almost all the analysed demonstrations were staged in big cities, the ESS5 data is limited to those living in 'a big city' or 'the suburbs or outskirts of a big city'. To conduct a more limited analysis of the social and political factors that make May Day participation more or less probable I also used data from the Swedish SOM Institute's national population survey. The CCC, ESS and SOM data has been coded according to the Oesch class scheme. ${ }^{3}$ In order to make it possible to identify the class position for those temporarily unemployed or retired, everyone has been included in the analysis. Furthermore, an extra tenth 'class' consisting of non-employed students has been added to the Oesch scheme. For more detailed information about this coding procedure and the ESS and SOM data, see Appendix.

\section{Analysis}

\section{Who Takes Part in May Day Demonstrations?}

With regard to the basic socio-economic features that are often analysed when political participation is discussed, we can see that the social profiles of the 15 CCC-surveyed May Day demonstrations display both similarities and differences. The variation is in part influenced by the profile of a specific demonstration - its main organizers and target constituency and how the May Day parade is framed. Furthermore, we can discern some systematic differences between the countries. This national variation should not of course be over-interpreted, because not all May Day marches can automatically be seen as representative of all possible May Day demonstrations in a specific country (especially in the countries where only one May Day parade was surveyed). Even so, the national variations can indicate significant differences that are due to specific national May Day cultures and more overall variations in national protest cultures.

As can be seen in Table 8.2, in general we find a higher percentage of men than women in the surveyed May Day demonstrations. However, the percentage of women varies both between and within countries. The highest percentage of 
Table 8.2 Socio-demographic characteristics for participants in May Day demonstrations surveyed within the CCC project

$$
\text { Belgium Italy Spain }
$$

Per cent (\%) Antwerp Florence Milan-EuroMayDay Barcelona Vigo- Vigo $\begin{array}{ll}C C O O-C I G & L O \\ \text { and } & \text { and } \\ U G T & \text { Democ }\end{array}$

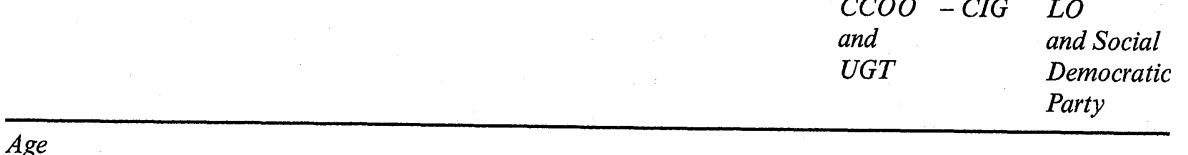

$30-49$ years

$50-64$ years

65 - years

Gender: female

Ethnicity: born

abroad

University

at university

Employment

situation

Work full-time

Work part-time

Freelance/

self-employed

(without

employed staff

Self-employed

with employed

Study full-time

between jobs

Retired/pensioner

Housewife/

househusband

'Precarious

conditions

$\begin{array}{rr}7 & \\ 27 & 23 \\ 41 & 50 \\ 24 & 20 \\ 34 & 47 \\ 3 & 2\end{array}$

3
23
50
20
47
2

36
50
9
2
53
1
73

11
36
39
12
32
6

$\begin{array}{rrr}3 & 13 & 13 \\ 53 & 55 & 22 \\ 35 & 28 & 34\end{array}$

$\begin{array}{rrr}35 & 28 & 34 \\ 9 & 4 & 31\end{array}$

$\begin{array}{rrr}42 & 38 & 49\end{array}$

Cases (N)

$\begin{array}{rrr}44 & 45 & 39 \\ 7 & 8 & 17 \\ 2 & 4 & 9\end{array}$

$\begin{array}{rrrr}62 & 71 & 66 & 47 \\ 3 & 5 & 5 & 8 \\ 3 & 0 & 2 & 2\end{array}$

209-216 $\quad 104-110 \quad 123-127$

$\begin{array}{rcrcr}4 & 0 & 2 & 1 & 1 \\ 13 & 6 & 3 & 8 & 9 \\ 5 & 7 & 14 & 16 & 2 \\ 5 & 16 & 8 & 5 & 30 \\ 0 & 1 & 6 & 3 & 5 \\ 30 & 14 & 18 & 23 & 11 \\ 127 & \mathbf{1 7 6 - 1 8 0} & \mathbf{6 6} & \mathbf{1 6 6 - 1 6 8} & \mathbf{1 7 3 - 1 7 6}\end{array}$

Notes: Used measure of association between the variables is Cramer's V. $*=5 \%, * *=1 \%$

and $* * *=0.1 \%$ significance; $n$.s. $=$ not significant.

women can be found in the EuroMayDay in Milan and the Swedish May Day demonstrations organized by the Left Party, the former organized by a radical left activist network and the latter by a left-socialist party.

Regarding age, most May Day demonstrations attract middle-aged and older people to a higher degree than young people. The highest percentage of young people (under 30) can be found in the May Day demonstrations in Milan, Zurich

\begin{tabular}{|c|c|c|c|c|c|c|c|c|}
\hline \multicolumn{5}{|c|}{ Sweden } & \multicolumn{2}{|c|}{ Switzerland } & \multicolumn{2}{|l|}{$\begin{array}{l}\text { United } \\
\text { Kingdom } \\
\end{array}$} \\
\hline $\begin{array}{l}\text { Stockholm } \\
\text { - Left } \\
\text { Party }\end{array}$ & $\begin{array}{l}\text { Malmö- } \\
\text { LO and } \\
\text { Social } \\
\text { Democratic } \\
\text { Party }\end{array}$ & $\begin{array}{l}\text { Malmö- } \\
\text { Left } \\
\text { Party }\end{array}$ & $\begin{array}{l}\text { Gothenburg } \\
-L O \text { and } \\
\text { Social } \\
\text { Democratic } \\
\text { Party }\end{array}$ & $\begin{array}{l}\text { Gothenburg } \\
\text { - Left } \\
\text { Party }\end{array}$ & Zurich & Geneva & London & Cramer's V \\
\hline 25 & 20 & 38 & 18 & 35 & 33 & 12 & 15 & $.290^{* * *}$ \\
\hline 29 & 29 & 38 & 29 & 33 & 39 & 28 & 34 & $.196^{* * *}$ \\
\hline 37 & 25 & 18 & 29 & 24 & 20 & 47 & 31 & $.221^{* * *}$ \\
\hline 9 & 25 & 5 & 23 & 8 & 7 & 13 & 15 & $249^{* * *}$ \\
\hline 60 & 44 & 50 & 53 & 58 & 44 & 47 & 34 & $.181^{* * *}$ \\
\hline 17 & 13 & 9 & 11 & 10 & 15 & 31 & 26 & $.275^{* * *}$ \\
\hline 79 & 51 & 79 & 45 & 83 & 62 & 59 & 79 & $.363^{* * *}$ \\
\hline 45 & 48 & 38 & 48 & 44 & 21 & 38 & 39 & $.221^{* * *}$ \\
\hline 14 & 7 & 18 & 6 & 22 & 45 & 29 & 11 & $.306^{* * *}$ \\
\hline 10 & 4 & 11 & 2 & 9 & 15 & 9 & 11 & $.170^{* * *}$ \\
\hline 2 & 2 & 0 & 0 & 1 & 1 & 1 & 1 & n.s. \\
\hline 21 & 14 & 29 & 12 & 21 & 15 & 7 & 11 & $.222 * * *$ \\
\hline 5 & 3 & 9 & 3 & 4 & 4 & 3 & 9 & $.169^{* * *}$ \\
\hline 10 & 24 & 5 & 23 & 10 & 7 & 18 & 17 & $.271 * * *$ \\
\hline 1 & 2 & 1 & 3 & 1 & 6 & 2 & 2 & $.104^{*}$ \\
\hline 25 & 12 & 33 & 11 & 31 & 58 & 37 & 28 & $.289 * * *$ \\
\hline $164-167$ & 95-97 & 139-141 & $155-160$ & 202-209 & $130-135$ & $202-206$ & $164-178$ & \\
\hline
\end{tabular}
and the Swedish May Day demonstrations staged by the Left Party. The highest percentage of demonstrators aged 65 years or more was in Antwerp and in the
Swedish May Day demonstrations organized by the trade union confederation LO and the Social Democratic Party. Also here, the general pattern is that May Day marches staged by radical left organizations and parties close to the 'new' social movements attract more young people and more women.

The percentage of May Day demonstrators born abroad (which can be seen as a proxy for ethnic minority status) does not follow a distinct pattern, but in comparison to the percentage of foreign-born among the general population, most May Day parades have a lower share of participants born 
in other countries. ${ }^{4}$ Only in three cases - Geneva, London and the Left Party demonstration in Stockholm - is the percentage of foreign-born higher. The slightly higher degree of foreign-born in the London and Stockholm May Day parades (and the lower degree in Barcelona, Milan and Zurich) is consistent with Morales's (2011) analysis of the political participation of immigrant groups in European cities, which includes six of the cities in our study. However, whereas Morales's study shows that immigrant groups in Geneva have a lower degree of protest participation than native-born Swiss, our May Day data shows the opposite. Given that the country of birth varies significantly within the group of foreign-born in this May Day demonstration, this could be an effect of Geneva being a 'global city' with international institutions and organizations whose employees also take part in May Day parades.

The percentage of May Day demonstrators with university education varies significantly, primarily between countries but also between demonstrations. The proportion of May Day participants with university education is particularly high in Italy, the UK and in the Swedish May Day demonstrations organized by the Left Party. The lowest figures are found in Belgium. The general pattern is thus that May Day demonstrations staged by radical left organizations attract the highest percentage of university-educated participants.

In Table 8.3, the three analytical categories of May Day demonstrations are compared with other types of trade union demonstrations, environmental protests and Pride parades. When comparing different types of protests and parades, the social composition of May Day demonstrations staged by the radical left is similar to that of environmental protests and Pride parades, i.e. demonstrations staged by 'new' social movements. On the other hand, May Day demonstrations staged by the major trade unions and social democratic parties resemble other types of trade union demonstrations.

Table 8.3 also shows the ESS5 data for the general population in larger cities. Although we can find differences in educational levels between different types of May Day demonstrations, the percentage of university-educated people is higher in all types of May Day marches than among the general population.

Before turning to the question of whether specific patterns can be discerned in May Day participants' class positions, other aspects of the individual's employment situation need to be highlighted. In the lower parts of Tables 8.2 and 8.3, figures for some labour market-related aspects of the individual's situation are shown, for instance whether she or he works full- or part-time, is self-employed, unemployed, studies full-time or is retired.

Peterson (Chapter 7) discusses whether the European labour movements have managed to organize the groups often seen as being hardest struck by the 2008 economic crisis. More recently, this group has been labelled 'the precariat' (e.g. Standing 2011). This group primarily consists of young people who are under- or unemployed and experience low degrees of social protection, despite the fact that they are often highly educated. Indications for

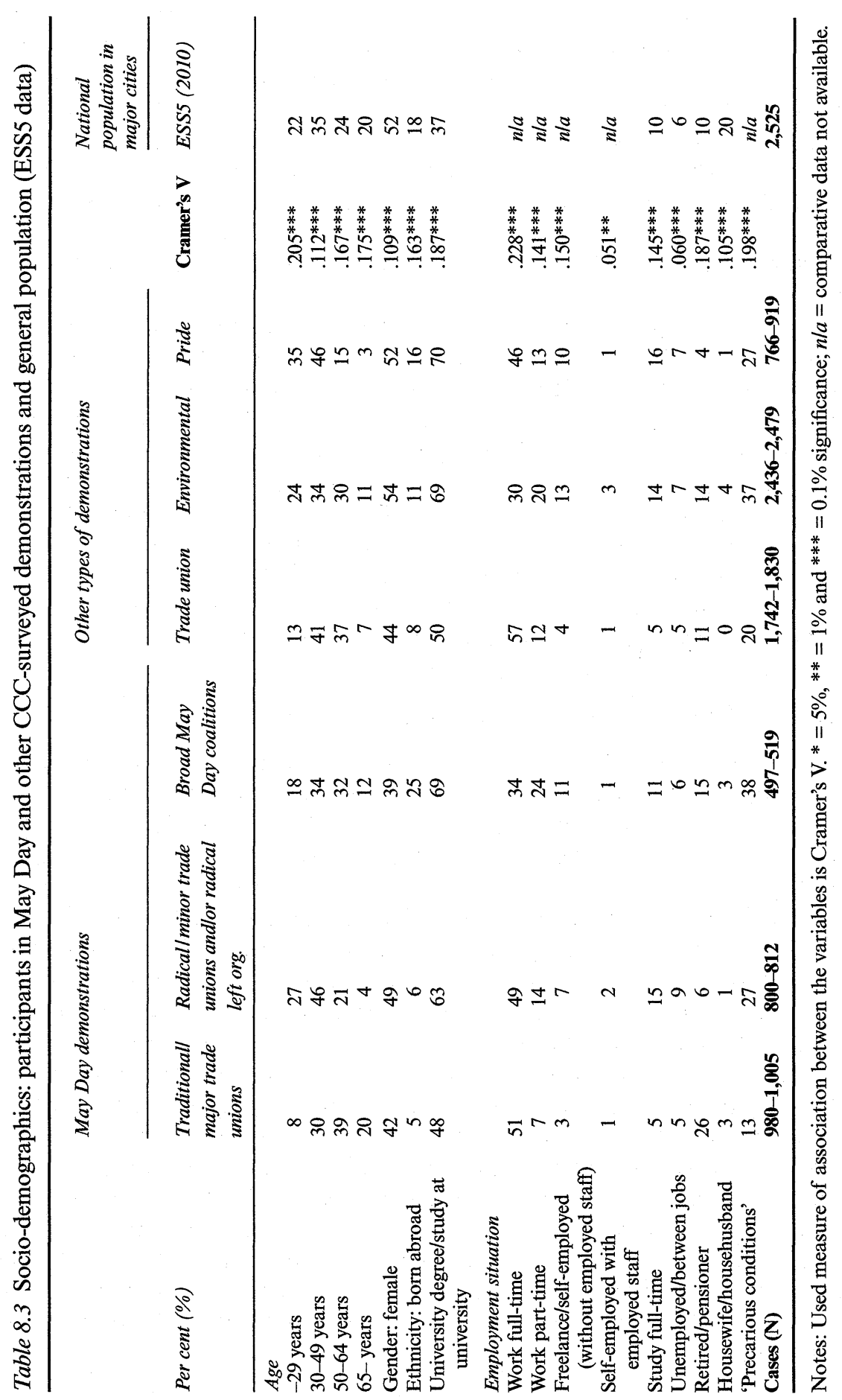




\section{Magnus Wennerhag}

some of the relevant aspects of the precariat's social situation can be found in Tables 8.2 and 8.3. These mainly concern under- and unemployment, which are conditions that lead to lower degrees of social protection. The same can be said for self-employed individuals, who, like the under- and unemployed, are excluded from the 'standard employment relationship' that gives direct access to high degrees of social protection, an arrangement that typically today is reserved for the fully employed 'salariat' only (Standing 2011). In both the tables a variable for the percentage of under- or unemployed or self-employed (without employed staff) has been added in order to show the proportion of protesters living under potentially 'precarious conditions'.

The highest degree of May Day participants living under such potentially 'precarious conditions' can be found in the Swiss and British demonstrations, and among the May Day demonstrations staged by the radical left. In the demonstrations organized by major trade unions and social democratic parties, this proportion is much lower. However, roughly the same percentage of protestors living under potentially 'precarious conditions' found in radical left May Day marches can also be found in environmental protests and Pride parades. Some parts of the European labour movements, particularly those connected with the radical left and/or new social movements, thus seem to mobilize individuals living under the social conditions characterizing 'the precariat', while the more traditional major trade unions do not do this to the same degree.

\section{The Class Composition of May Day Demonstrations}

What is the social class composition of May Day demonstrations? As discussed earlier, class can be perceived as both a matter of the individual's 'objective' position in a hierarchically structured labour market and his or her 'subjective' sense of belonging to a social class, i.e. the individual's class identity.

Table 8.4 clarifies the class composition (according to the Oesch-9 class scheme) of the surveyed May Day demonstrations, and in Table 8.5 the corresponding ESS data for the general population of larger cities is shown. The traditional working class, which historically was mobilized in May Day demonstrations, is a group that in general is relatively weakly represented in all the surveyed demonstrations. The total percentage of individuals in the Oesch-9 classes belonging to this group - office clerks, production workers and service workers - at most adds up to 38 per cent (in two Swedish May Day parades arranged by LO and the Social Democratic Party), but on average oscillates around 23 per cent. Among the traditional working class it is primarily production workers who demonstrate on May Day. If we compare the May Day demonstrators with the general population (see Table 8.5), the proportion of individuals with working-class occupations in the May Day parades is more or less half that of the corresponding figure for the general population.
Who Takes Part in May Day Marches? 199

One explanation for this perhaps surprising pattern can found in one of the Oesch-9 classes belonging to the occupational middle class (i.e. employees and professionals), namely associate managers and administrators - a group that on average accounts for around 20 per cent of May Day demonstrators. Among the demonstrations organized by major trade unions, this proportion is even higher; in some cases just under 40 per cent. Due to the construction of the Oesch categories, this group also includes trade union officials and party functionaries. The relatively high proportion of associate managers and administrators could then be seen as an indirect result of the institutionalization and professionalization of the labour movement. From the perspective of occupational-based class categorizations, the car factory worker who goes from being a shop-floor union activist to a paid union official is transformed from a worker into a middle class employee.

Among the occupational middle classes we also find the Oesch-9 class, which has the largest proportion of May Day demonstrators: socio-cultural professionals and semi-professionals. In this class we find teachers (at all educational levels), medical doctors and nurses, social work professionals, journalists, etc. This class in particular dominates May Day demonstrations in Switzerland, the UK and the Swedish May Day demonstrations organized by the Left Party. These are also the May Day demonstrations in which we find a somewhat higher proportion of self-employed professionals, even though overall this group is quite small in the May Day marches. In this class we find people working in the media or as artists, authors, etc. However, if we compare the percentage of this Oesch class with the corresponding figure for the general population (see Table 8.5 ), most May Day marches mobilize a higher proportion of self-employed professionals than can be found in the general population. Table 8.5 also shows that the proportion of socio-cultural professionals and semi-professionals is much higher in May Day demonstrations than among the general population.

In general, the trade unionists and other protestors who are mobilized in contemporary May Day demonstrations are more often from the occupational middle classes than from the occupations that traditionally constituted the working class. In comparison with the ESS data for the general population, the proportion of occupational middle class who take part in May Day marches is much greater. However, if we compare May Day marches with demonstrations staged by 'new' social movements (see Table 8.5), we still find that a higher proportion of individuals with working-class occupations take to the streets on May Day. Also, the May Day parades staged by major trade unions and social democratic parties attract the highest proportion of working class. In short, even though May Day parades do not mobilize as high a percentage of working-class individuals as can be found in the general population, they nevertheless mobilize a higher share of this class than demonstrations staged by new social movements. 
Table 8.4 Class composition (Oesch-9) in May Day demonstrations surveyed within the CCC project

\begin{tabular}{|c|c|c|c|c|c|c|c|}
\hline \multirow[b]{2}{*}{ Per cent $(\%)$} & \multirow{2}{*}{$\begin{array}{l}\text { Belgium } \\
\text { Antwerp }\end{array}$} & \multicolumn{2}{|r|}{ Italy } & \multicolumn{2}{|l|}{ Spain } & \multirow[b]{2}{*}{$\begin{array}{l}\text { Vigo- } \\
\text { CIG }\end{array}$} & \multirow[b]{2}{*}{$\begin{array}{l}\text { Stockholm- } \\
\text { LO and } \\
\text { Social } \\
\text { Democratic } \\
\text { Party }\end{array}$} \\
\hline & & Florence & Milan-EuroMayDay & Barcelona & $\begin{array}{l}\text { Vigo- } \\
\text { CCOO } \\
\text { and UGT }\end{array}$ & & \\
\hline $\begin{array}{l}\text { Self-employed } \\
\text { Large employers } \\
\text { (10 or more } \\
\text { emplovees) }\end{array}$ & 0 & 1 & 2 & 1 & 0 & 0 & 2 \\
\hline $\begin{array}{l}\text { Self-employed } \\
\text { professionals }\end{array}$ & 2 & 1 & 6 & 1 & 0 & 1 & 1 \\
\hline $\begin{array}{l}\text { Small business } \\
\text { owners }\end{array}$ & 1 & 1 & 4 & 2 & 0 & 2 & 0 \\
\hline \multicolumn{8}{|c|}{ Employed: Professionals and employees } \\
\hline $\begin{array}{l}\text { Associate } \\
\text { managers and } \\
\text { administrators }\end{array}$ & 37 & 37 & 17 & 30 & 33 & 29 & 35 \\
\hline $\begin{array}{l}\text { Technical } \\
\text { professionals } \\
\text { and } \\
\text { technicians }\end{array}$ & 8 & 4 & 5 & 13 & 6 & 8 & 6 \\
\hline $\begin{array}{l}\text { Socio-cultural } \\
\text { professionals } \\
\text { and semi- } \\
\text { professionals }\end{array}$ & 20 & 27 & 28 & 30 & 25 & 22 & 21 \\
\hline \multicolumn{8}{|l|}{ Employed: Workers } \\
\hline $\begin{array}{l}\text { Office clerks } \\
\text { Production }\end{array}$ & $\begin{array}{r}7 \\
14\end{array}$ & $\begin{array}{l}6 \\
9\end{array}$ & $\begin{array}{l}4 \\
7\end{array}$ & $\begin{array}{r}1 \\
10\end{array}$ & $\begin{array}{r}2 \\
22\end{array}$ & $\begin{array}{r}3 \\
22\end{array}$ & $\begin{array}{r}5 \\
12\end{array}$ \\
\hline Service workers & 7 & 10 & 14 & 5 & 10 & 5 & 10 \\
\hline $\begin{array}{c}\text { Students not } \\
\text { working }\end{array}$ & 5 & 1 & 13 & 7 & 2 & 9 & 8 \\
\hline Cases (N) & 172 & 67 & 83 & 132 & 51 & 129 & 170 \\
\hline
\end{tabular}

Notes: Used measure of association between the variables is Cramer's V. $*=5 \%, * *=1 \%$ and $* * *=0.1 \%$ significance; $n . s$. $=$ not significant.

With regard to the more 'subjective' side of class - class identity - other patterns can be identified (see Table 8.6), which depend more on the country in which the May Day demonstration is staged. On average, the percentage of demonstrators identifying themselves as (upper or lower) middle class is higher than that identifying as working class. The only countries where those identifying as working class dominate are Spain and the UK. This seems to indicate that class identification is more dependent on national discourses of class, the organizers of the May Day parade etc., than on individuals' positions in the labour market.

However, Table 8.7 illustrates that even though the proportion of May Day demonstrators identifying themselves as working class is on average lower than those identifying as middle class, the percentage of those who perceive themselves as working class is considerably higher among May Day demonstrators than

\begin{tabular}{|c|c|c|c|c|c|c|c|c|}
\hline \multicolumn{5}{|c|}{ Sweden } & \multicolumn{2}{|c|}{ Switzerland } & \multicolumn{2}{|l|}{$\begin{array}{l}\text { United } \\
\text { Kingdom }\end{array}$} \\
\hline $\begin{array}{l}\text { Stockholm- } \\
\text { Left Party }\end{array}$ & $\begin{array}{l}\text { Malmö-LO } \\
\text { and Social } \\
\text { Democratic } \\
\text { Party }\end{array}$ & $\begin{array}{l}\text { Malmö- } \\
\text { Left Party }\end{array}$ & $\begin{array}{l}\text { Gothenburg - } \\
\text { LO and Social } \\
\text { Democratic } \\
\text { Party }\end{array}$ & $\begin{array}{l}\text { Gothenburg - } \\
\text { Left Party }\end{array}$ & Zurich & Geneva & London & Cramer's V \\
\hline 3 & 1 & 1 & 1 & 1 & 3 & 1 & 1 & n.s. \\
\hline 6 & 2 & 8 & 1 & 6 & 13 & 6 & 8 & $.166^{* * *}$ \\
\hline 2 & 2 & 3 & 1 & 2 & 2 & 3 & 3 & n.s. \\
\hline 12 & 10 & 6 & 16 & 11 & 11 & 30 & 22 & $.258 * * *$ \\
\hline 6 & 2 & 4 & 8 & 9 & 8 & 7 & 8 & n.s. \\
\hline 40 & 27 & 37 & 23 & 40 & 39 & 37 & 36 & $.165^{* * *}$ \\
\hline $\begin{array}{l}2 \\
4\end{array}$ & $\begin{array}{c}7 \\
19\end{array}$ & $\begin{array}{l}4 \\
5\end{array}$ & $\begin{array}{r}4 \\
19\end{array}$ & $\begin{array}{l}4 \\
6\end{array}$ & $\begin{array}{l}2 \\
6\end{array}$ & $\begin{array}{l}2 \\
5\end{array}$ & $\begin{array}{l}4 \\
4\end{array}$ & $\begin{array}{l}\text { n.s. } \\
.200^{* * *}\end{array}$ \\
\hline 6 & 13 & 8 & 15 & 5 & 4 & 3 & 4 & $.133^{* *}$ \\
\hline 18 & 16 & 25 & 13 & 18 & 13 & 6 & 11 & $.191^{* * *}$ \\
\hline 158 & 86 & 132 & 142 & 197 & 112 & 174 & 160 & \\
\hline
\end{tabular}

among participants in protests and parades staged by new social movements. We can thus conclude that although May Day demonstrations to a certain extent mobilize more individuals identifying as middle class than individuals seeing themselves as working class, they still mobilize a higher share of people with a working-class identity than demonstrations staged by new social movements.

Having said this, the percentage of those identifying themselves as working class is on average almost double ( 40 per cent) the percentage of demonstrators with working-class occupations ( 23 per cent). This shows that 'objective' class does not necessarily coincide with 'subjective' class, and clearly indicates that the latter seems to be much more central for participation in May Day parades. The question is to what degree this difference between 'objective' class and class identity can be attributed to other factors, such as the above-mentioned cross-country difference. 
In order to test which social (and political) factors contribute most to May Day demonstrators' identification as either working or middle class, a binary logistic regression was conducted (see Table 8.8)..$^{5}$ In the regression, control variables for age, gender and educational level were included, in addition to variables for the country of the demonstration, the individual's belonging to a specific Oesch-9 class, as well as political orientation on the left-right spectrum.

In general, the May Day demonstrators' class identity is affected most by the country in which the demonstration was held. For example, Spanish May Day demonstrators are more than eight times as likely to identify as working class as those participating in Swedish May Day demonstrations. Nevertheless, and not surprisingly, the individual's 'objective' class position is also an important determinant for class identity. For example, a working-class occupation makes it between three and six times as probable for an individual to identify with the working class (compared to those with other objective class positions).

Other factors that influence class identification are university education (the highly educated more often identify themselves with the middle class) and unemployment (the unemployed identify themselves more often with the working class), as well as the individual's placement on the left-right scale. Individuals who place themselves as decidedly left on the scale are much more prone to identify themselves as working class. Thus, class identity also seems to be a matter of political orientation.

\section{What Kind of Social and Political Factors Influence an} Individual's Decision to Join a May Day Parade?

What kind of social and political factors make May Day participation more probable at the individual level? Do socio-demographic factors such as class, age and gender play the most decisive role for joining a May Day demonstration, or do other factors, such as individuals' organizational belonging or their political attitudes, play a more important role?

In order to answer these questions I have 'pooled' data from the six CCC May Day surveys that were conducted in Sweden from 2010-2012 with similar data from the Swedish SOM Institute's national population survey for 2011 (see the Appendix for a more detailed discussion of this procedure). In this SOM Institute survey, respondents were asked whether they had participated in a May Day demonstration during the last 12 months. The analysis is limited to Sweden's three largest cities in which the CCC protest surveys were conducted. In this way, a comparison can be made between the individuals taking part in the main May Day marches in these cities and those who said they did not participate.

In Tables 8.9 and 8.10 , the results of analyses of a set of different factors that contribute to May Day participation are shown. A binary logistic regression has been made for each model. In the first model (Table 8.9), the impact of socio-demographic standard variables is analysed. In the second model, the impact of occupational class according to Oesch is analysed separately 
Table 8.6 Class identification among participants in May Day demonstrations surveyed within the CCC project

\begin{tabular}{|c|c|c|c|c|c|c|c|}
\hline \multirow[b]{2}{*}{ Per cent $(\%)$} & \multirow{2}{*}{$\begin{array}{l}\text { Belgium } \\
\text { Antwerp }\end{array}$} & \multicolumn{2}{|r|}{ Italy } & \multicolumn{3}{|c|}{ Spain } & \multirow[b]{2}{*}{$\begin{array}{l}\text { Stockholm- } \\
\text { LO and } \\
\text { Social } \\
\text { Democratic } \\
\text { Party }\end{array}$} \\
\hline & & Florence & Milan-EuroMayDay & Barcelona & $\begin{array}{l}\text { Vigo-- } \\
\text { CCOO } \\
\text { and } \\
U G T\end{array}$ & $\begin{array}{l}\text { Vigo- } \\
\text { CIG }\end{array}$ & \\
\hline Upper class & 0 & 0 & 0 & 0 & 0 & 1 & 0 \\
\hline $\begin{array}{l}\text { Upper middle } \\
\text { class }\end{array}$ & 13 & 12 & 25 & 5 & 9 & 2 & 26 \\
\hline $\begin{array}{l}\text { Lower middle } \\
\text { class }\end{array}$ & 41 & 58 & 49 & 17 & 14 & 11 & 42 \\
\hline Working class & 35 & 24 & 14 & 77 & 73 & 84 & 29 \\
\hline Lower class & 2 & 1 & 7 & 1 & 3 & 1 & 0 \\
\hline None & 9 & 5 & 5 & 1 & 0 & 1 & 3 \\
\hline Cases $(\mathrm{N})$ & 211 & 106 & 124 & 173 & 64 & 166 & 168 \\
\hline
\end{tabular}

Notes: Used measure of association between the variables is Cramer's V. * $=5 \%, * *=1 \%$ and $* * *=0.1 \%$ significance; $n . s$. $=$ not significant.

and in the third model both occupational class and class identity are analysed in the same model. In the fourth model, all socio-demographic and class variables are analysed simultaneously.

In the two last models (Table 8.10), a row of other variables concerning organizational belonging and political attitudes are introduced: organizational affiliation, identification with specific political parties, left-right placement, political trust and satisfaction with democracy. This is done in two steps: first by introducing variables concerning political attitudes and ideology in the fifth model, and then by adding variables concerning organizational affiliation in the sixth model.

With regard to the socio-demographic standard variables analysed in Model 1, some factors are more important than others for explaining May Day participation. In particular, young people and those with a university education are more likely to take part in May Day marches. Even though Model 2 produces relatively minor differences for the factors that are statistically significant, it still shows that occupational class affects individuals' likelihood to join a May Day parade. Compared to production workers, socio-cultural professionals and semi-professionals are more inclined to demonstrate on May Day, although at the same time associate managers and administrators, office clerks and small business owners are less inclined to demonstrate than production workers. When class identity is introduced in Model 3, this shows that also when controlling for occupational class a working-class identity makes people more predisposed to participating in May Day demonstrations. When all the standard socio-demographic and class variables from previous models are analysed together in Model 4, most of the significant

\begin{tabular}{|c|c|c|c|c|c|c|c|c|}
\hline \multicolumn{5}{|l|}{ Sweden } & \multicolumn{2}{|c|}{ Switzerland } & \multicolumn{2}{|l|}{$\begin{array}{l}\text { United } \\
\text { Kingdom }\end{array}$} \\
\hline $\begin{array}{l}\text { Stockholm } \\
\text { - Left } \\
\text { Party }\end{array}$ & $\begin{array}{l}\text { Malmö-LO } \\
\text { and Social } \\
\text { Democratic } \\
\text { Party }\end{array}$ & $\begin{array}{l}\text { Malmö- } \\
\text { Left } \\
\text { Party }\end{array}$ & $\begin{array}{l}\text { Gothenburg- } \\
\text { LO and Social } \\
\text { Democratic } \\
\text { Party }\end{array}$ & $\begin{array}{l}\text { Gothenburg- } \\
\text { Left Party }\end{array}$ & Zurich & Geneva & London & Cramer's V \\
\hline $\begin{array}{r}0 \\
20\end{array}$ & $\begin{array}{r}0 \\
13\end{array}$ & $\begin{array}{r}0 \\
17\end{array}$ & $\begin{array}{r}0 \\
17\end{array}$ & $\begin{array}{r}0 \\
15\end{array}$ & $\begin{array}{r}1 \\
20\end{array}$ & $\begin{array}{r}1 \\
41\end{array}$ & $\begin{array}{r}1 \\
11\end{array}$ & $\begin{array}{l}\text { n.s. } \\
.260^{* * *}\end{array}$ \\
\hline 53 & 38 & 49 & 35 & 55 & 41 & 35 & 20 & $.295^{* * *}$ \\
\hline 20 & 43 & 30 & 44 & 27 & 23 & 17 & 57 & $\begin{array}{l}.447^{* * * *} \\
135 * *\end{array}$ \\
\hline $\begin{array}{l}1 \\
6\end{array}$ & $\begin{array}{l}1 \\
5\end{array}$ & 1 & 1 & $\begin{array}{l}1 \\
2\end{array}$ & $\begin{array}{r}4 \\
11\end{array}$ & $\begin{array}{l}0 \\
6\end{array}$ & $\begin{array}{l}1 \\
9\end{array}$ & $\begin{array}{l}.135^{* * *} \\
.154^{* * * *}\end{array}$ \\
\hline $\begin{array}{r}0 \\
162\end{array}$ & $\begin{array}{r}5 \\
95\end{array}$ & $\begin{array}{r}2 \\
138\end{array}$ & $\begin{array}{r}3 \\
156\end{array}$ & $\begin{array}{r}2 \\
206\end{array}$ & 132 & 201 & 167 & \\
\hline
\end{tabular}

differences between the different factors remain. However, the significance for socio-cultural professionals and semi-professionals disappears, at the same time as the impact of university education becomes stronger. This shows that the likelihood of members of this occupational class taking part in May Day marches is closely correlated to a higher level of education. Models $1-4$, all of which deal with socio-demographic predictors for May Day participation, only explain between 4 and 12 per cent of the variation (see Nagelkerke's pseudo- $\mathrm{R}^{2}$ for the different models). It can thus be concluded that class and other socio-demographic factors influence individuals' decisions to demonstrate on May Day, although their forecasting potential is minor.

When the set of variables relating to political attitudes, ideology and organizational affiliation are introduced in Models 5-6 (Table 8.10), these models explain between 67 and 74 per cent of the variation (which is relatively rare when dealing with these types of survey-based social and attitudinal statistics) becomes clearer. Political and ideological factors, as well as organizational membership, play a more decisive role than socio-demographic factors in explaining why certain groups are more likely to join a May Day demonstration than other groups.

The single most determining factor is party membership, i.e. organizational affiliation. Party members are almost 16 times more likely to join a May Day demonstration than non-party members. Also, sympathies with certain political parties play an important role, which is perhaps less surprising. Left Party sympathizers are twice as likely to demonstrate on May Day than Social Democratic Party sympathizers. However, in comparison with Social Democratic Party sympathizers (and the quite small Feminist Party), those 
Table 8.7 Class identification: participants in May Day and other CCC-surveyed demonstrations

\begin{tabular}{|c|c|c|c|c|c|c|c|}
\hline \multirow[b]{2}{*}{ Per cent $(\%)$} & \multicolumn{3}{|c|}{ May Day demonstrations } & \multicolumn{3}{|c|}{ Other types of demonstrations } & \multirow[b]{2}{*}{ Cramer's V } \\
\hline & $\begin{array}{l}\text { Traditionall } \\
\text { major trade } \\
\text { unions }\end{array}$ & $\begin{array}{l}\text { Radical/minor } \\
\text { trade unions } \\
\text { andlor radical } \\
\text { left org. }\end{array}$ & $\begin{array}{l}\text { Broad May Day } \\
\text { coalitions }\end{array}$ & Trade union & Environmental & Pride & \\
\hline Upper class & 0 & 0 & 1 & 0 & 1 & 1 & $.040 *$ \\
\hline Upper middle class & 13 & 15 & 21 & 13 & 27 & 25 & $.156 * * *$ \\
\hline Lower middle class & 38 & 38 & 29 & 38 & 46 & 46 & $.103 * * *$ \\
\hline Working class & 43 & 42 & 38 & 40 & 11 & 16 & $.314 * * *$ \\
\hline Lower class & 1 & 3 & 2 & 1 & 1 & 2 & $.041 *$ \\
\hline None & 4 & 3 & 9 & 8 & 14 & 10 & $.135 * * * *$ \\
\hline $\operatorname{Cases}(\mathrm{N})$ & 973 & 796 & 500 & 1763 & 2408 & 897 & \\
\hline
\end{tabular}

Notes: Used measure of association between the variables is Cramer's V. $*=5 \%, * *=1 \%$ and ${ }^{* * *}=0.1 \%$ significance.

Table 8.8 Binary logistic regression for determinants of working-class and middle-class identification (CCC data)

\begin{tabular}{|c|c|c|c|c|c|c|}
\hline & \multicolumn{3}{|l|}{ Model 1} & \multicolumn{3}{|l|}{ Model 2} \\
\hline & \multicolumn{3}{|c|}{ Working-class identification } & \multicolumn{3}{|c|}{ Middle-class identification } \\
\hline & $B$ & S.E. & $\operatorname{Exp}(B)$ & $B$ & S.E. & $\operatorname{Exp}(B$ \\
\hline \multicolumn{7}{|l|}{ Control variables } \\
\hline \multicolumn{7}{|l|}{ Age $(29$ years and younger $=$ ref. $)$} \\
\hline $30-49$ years & 0.25 & 0.20 & 1.28 & -0.03 & 0.18 & 0.97 \\
\hline 50-64 years & 0.13 & 0.21 & 1.14 & 0.17 & 0.19 & 1.18 \\
\hline 65 years and older & 0.41 & 0.24 & 1.51 & -0.13 & 0.22 & 0.88 \\
\hline Gender: female & $-0.38 * *$ & 0.12 & 0.68 & $0.41^{* * *}$ & 0.12 & 1.51 \\
\hline Ethnicity: born abroad & $0.45^{*}$ & 0.19 & 1.56 & $-0.56^{* *}$ & 0.18 & 0.57 \\
\hline University degree/study at university & $-1.13^{* * *}$ & 0.14 & 0.32 & $1.10 * * *$ & 0.14 & 3.01 \\
\hline Unemployed or between jobs & $0.75^{* *}$ & 0.28 & 2.12 & $-0.93 * *$ & 0.29 & 0.40 \\
\hline \multicolumn{7}{|l|}{ Country of demonstration (Sweden $=$ ref.) } \\
\hline Belgium & $-0.44^{*}$ & 0.22 & 0.64 & 0.05 & 0.21 & 1.05 \\
\hline Italy & $-1.03^{* * *}$ & 0.26 & 0.36 & $0.51^{*}$ & 0.23 & 1.66 \\
\hline Spain & $2.14 * * *$ & 0.18 & 8.53 & $-2.05 * * *$ & 0.18 & 0.13 \\
\hline Switzerland & $-0.76^{* * *}$ & 0.20 & 0.47 & $0.42^{*}$ & 0.18 & 1.51 \\
\hline United Kingdom & $1.53 * * *$ & 0.22 & 4.61 & $-1.61 * * *$ & 0.22 & 0.20 \\
\hline \multicolumn{7}{|c|}{ Class: Oesch-9 scheme (socio-cultural professionals and semi-professionals $=$ ref.) } \\
\hline Large employers (10 or more employees) & -0.24 & 0.68 & 0.79 & -0.12 & 0.57 & 0.89 \\
\hline Self-employed professionals & -0.03 & 0.34 & 0.97 & -0.43 & 0.29 & 0.65 \\
\hline Small business owners & 0.14 & 0.43 & 1.15 & -0.49 & 0.41 & 0.62 \\
\hline Associate managers and administrators & 0.22 & 0.17 & 1.24 & -0.01 & 0.16 & 0.99 \\
\hline Technical professionals and technicians & 0.44 & 0.25 & 1.55 & -0.40 & 0.23 & 0.67 \\
\hline
\end{tabular}


sympathizing with the Green Party are only a quarter as likely to join a May Day demonstration, and the corresponding figure for the remaining parties (all of which are in principle right or centre-right orientated) is one tenth. As we might expect, those positioning themselves as 'right' on the left-right spectrum are also much less (less than one tenth, in terms of odds ratio) likely to demonstrate on May Day.

Another important factor is dissatisfaction with how democracy works at the national level. Those participants dissatisfied with Swedish democracy are almost twice as likely to demonstrate on May Day in comparison with those satisfied with Swedish democracy. This confirms the importance of the actual political situation for mobilizing people to May Day demonstrations. In the surveyed years 2010-2012, Sweden was led by a right-wing government, and dissatisfaction with its policies apparently influenced individuals' decisions to join the May Day marches staged by two of the main opposition parties.

It can thus be concluded that organizational affiliation with a political party is the single most important factor that influences individuals' decisions to demonstrate on May Day. However, party sympathies, general ideological orientation and dissatisfaction with democracy at the national level are also important factors. All these findings resonate well with previous research on which factors primarily influence individuals to participate in political protests. For example, social-psychological research stresses that the prime motives for individuals' political participation are social (that one knows other politically active people), ideological (that one shares the political values of a movement or an organization) and instrumental (that one believes that one's own participation can have an impact) (see e.g. Klandermans 2004 and Chapter 9 in this volume). While we can corroborate that ideological and social aspects are important for participation in May Day demonstrations, we cannot test the participants' instrumental motives due to the lack of compatible data.

Nevertheless, we can say that social class matters for May Day participation, even though it does not matter in the same way (or to the same degree) as organizational and political factors. In contrast to the dominant picture of May Day demonstrations as historically primarily mobilizing the working class - or at least the organized working class - the results are more ambivalent. On the one hand, individuals with certain types of working-class occupations (such as production or service workers) are as likely to demonstrate on May Day as individuals having certain types of middle class occupations are (for instance technical professionals and technicians). On the other hand, it is clear that the specific middle-class group of socio-cultural professionals and semi-professionals is mobilized to a much higher degree than all other occupational classes. From a historical perspective, this at least says something about how the types of wage-labourers mobilized by May Day parades have changed over time. Given the lack of similar data for the rest of our analysed countries, it is of course difficult to generalize for Western Europe as a whole. The large percentage of socio-cultural professionals and semi-professionals could be attributable to specific Swedish conditions, such as the country's 
Table 8.9 Binary logistic regression: factors contributing to May Day participation (CCC and SOM institute data), part 1

\begin{tabular}{|c|c|c|c|c|c|c|c|c|c|c|c|c|}
\hline & \multicolumn{3}{|l|}{ Model 1} & \multicolumn{3}{|l|}{ Model 2} & \multicolumn{3}{|l|}{ Model 3} & \multicolumn{3}{|l|}{ Model 4} \\
\hline & \multicolumn{3}{|c|}{ Only control variables } & \multicolumn{3}{|c|}{ Only occupational class } & \multicolumn{3}{|c|}{$\begin{array}{l}\text { Only occupational class and } \\
\text { class identity }\end{array}$} & \multicolumn{3}{|c|}{$\begin{array}{l}\text { Control variables, occupational } \\
\text { class and class identity }\end{array}$} \\
\hline & $B$ & S.E. & $\operatorname{Exp}(B)$ & $B$ & S.E. & $\operatorname{Exp}(B)$ & $B$ & S.E. & $\operatorname{Exp}(B)$ & $B$ & S.E. & $\operatorname{Exp}(B)$ \\
\hline \multicolumn{13}{|l|}{ Control variables } \\
\hline \multicolumn{13}{|l|}{ Age $(29$ years and younger $=$ ref. $)$} \\
\hline $30-49$ years & $-0.68 * * *$ & 0.17 & 0.50 & & & & & & & $-0.62 * *$ & 0.20 & 0.54 \\
\hline $50-64$ years & -0.28 & 0.18 & 0.76 & & & & & & & -0.20 & 0.22 & 0.82 \\
\hline 65 years and older & $-0.56^{* *}$ & 0.19 & 0.57 & & & & & & & -0.30 & 0.24 & 0.74 \\
\hline Gender: female & $-0.21 \dagger$ & 0.12 & 0.81 & & & & & & & -0.15 & 0.13 & 0.87 \\
\hline $\begin{array}{l}\text { Ethnicity: born/grown up in another } \\
\text { country }\end{array}$ & -0.02 & 0.18 & 0.98 & & & & & & & 0.14 & 0.21 & 1.15 \\
\hline University degree/study at university & $0.54 * * *$ & 0.12 & 1.71 & & & & & & & $0.63^{* * *}$ & 0.16 & 1.87 \\
\hline \multicolumn{13}{|l|}{$\begin{array}{l}\text { Class: Oesch-9 scheme (production } \\
\text { workers }=\text { ref.) }\end{array}$} \\
\hline Large employers (10 or more employees) & & & & -0.21 & 0.51 & 0.81 & 0.35 & 0.56 & 1.41 & -0.12 & 0.59 & 0.89 \\
\hline Self-employed professionals & & & & 0.35 & 0.38 & 1.41 & 0.61 & 0.41 & 1.84 & 0.13 & 0.43 & 1.14 \\
\hline Small business owners & & & & $-1.32 * * *$ & 0.40 & 0.27 & $-0.89^{*}$ & 0.42 & 0.41 & $-1.31 * *$ & 0.46 & 0.27 \\
\hline Associate managers and administrators & & & & $-0.51^{*}$ & 0.23 & 0.60 & -0.30 & 0.25 & 0.74 & $-0.58^{*}$ & 0.27 & 0.56 \\
\hline Technical professionals and technicians & & & & -0.44 & 0.28 & 0.64 & -0.26 & 0.29 & 0.77 & $-0.69^{*}$ & 0.32 & 0.50 \\
\hline $\begin{array}{l}\text { Socio-cultural professionals/ } \\
\text { semi-professionals }\end{array}$ & & & & $0.49^{*}$ & 0.23 & 1.64 & $0.70^{* *}$ & 0.24 & 2.01 & 0.23 & 0.28 & 1.26 \\
\hline Office clerks & & & & $-0.83^{*}$ & 0.30 & 0.44 & $-0.74^{*}$ & 0.30 & 0.48 & $-0.93 * *$ & 0.33 & 0.40 \\
\hline Service workers & & & & -0.15 & 0.27 & 0.86 & -0.10 & 0.27 & 0.90 & -0.21 & 0.30 & 0.81 \\
\hline Students not working & & & & 0.40 & 0.26 & 1.50 & $0.63^{*}$ & 0.27 & 1.89 & 0.07 & 0.32 & 1.07 \\
\hline \multicolumn{13}{|l|}{ Class identity (working class $=$ ref.) } \\
\hline Middle class & & & & & & & $-0.30 \dagger$ & 0.15 & 0.74 & $-0.44 * *$ & 0.17 & 0.65 \\
\hline Other class & & & & & & & $-1.03 * * *$ & 0.30 & 0.36 & $-1.13^{* * *}$ & 0.31 & 0.32 \\
\hline Constant & $-4.84 * * *$ & 0.17 & 2.55 & $-5.03 * * *$ & 0.19 & 2.12 & $-4.93 * * *$ & 0.20 & 2.34 & $-4.48 * * *$ & 0.28 & 3.68 \\
\hline Nagelkerke's pseudo- $\mathbf{R}^{2}$ & 0.040 & & & 0.073 & & & 0.086 & & & 0.115 & & \\
\hline Observations & 1356 & & & 1329 & & & 1294 & & & 1250 & & \\
\hline
\end{tabular}

Notes: Columns show beta coefficient, standard error and odds ratio. Levels of significance: $\uparrow=10 \%, *=5 \%, * *=1 \%$ and $* * *=0.1 \%$ significance.

Table 8.10 Binary logistic regression: factors contributing to May Day participation (CCC and SOM institute data), part 2

\begin{tabular}{|c|c|c|c|c|c|c|}
\hline & \multicolumn{3}{|l|}{ Model 5} & \multicolumn{3}{|l|}{ Model 6} \\
\hline & \multicolumn{3}{|c|}{$\begin{array}{l}\text { Including political and ideological } \\
\text { variables }\end{array}$} & \multicolumn{3}{|c|}{ Including organizational variables } \\
\hline & $B$ & S.E. & $\operatorname{Exp}(B)$ & $B$ & S.E. & $\operatorname{Exp}(B)$ \\
\hline \multicolumn{7}{|l|}{ Control variables } \\
\hline \multicolumn{7}{|l|}{ Age $(29$ years and younger $=$ ref. $)$} \\
\hline $30-49$ years & -0.26 & 0.31 & 0.77 & -0.29 & 0.36 & 0.75 \\
\hline $50-64$ years & -0.16 & 0.33 & 0.86 & -0.02 & 0.38 & 0.98 \\
\hline 65 years and older & 0.05 & 0.39 & 1.05 & 0.12 & 0.44 & 1.12 \\
\hline Gender: female & $-0.38 \dagger$ & 0.21 & 0.69 & -0.34 & 0.24 & 0.71 \\
\hline Ethnicity: born/grown up in another country & $0.62 \dagger$ & 0.34 & 1.85 & $0.67 \dagger$ & 0.39 & 1.96 \\
\hline University degree/study at university & $0.80^{* *}$ & 0.26 & 2.24 & $0.63^{*}$ & 0.29 & 1.88 \\
\hline \multicolumn{7}{|l|}{ Class: Oesch-9 scheme (production workers = ref.) } \\
\hline Large employers ( 10 or more employees) & -0.16 & 1.03 & 0.86 & -1.09 & 1.13 & 0.34 \\
\hline Self-employed professionals & 0.95 & 0.68 & 2.58 & 0.97 & 0.73 & 2.64 \\
\hline Small business owners & -0.97 & 0.67 & 0.38 & -1.14 & 0.71 & 0.32 \\
\hline Associate managers and administrators & -0.27 & 0.43 & 0.76 & $-0.95^{*}$ & 0.48 & 0.39 \\
\hline Technical professionals and technicians & 0.03 & 0.50 & 1.03 & -0.22 & 0.58 & 0.80 \\
\hline Socio-cultural professionals/semi-professionals & -0.04 & 0.43 & 0.96 & -0.20 & 0.48 & 0.82 \\
\hline Office clerks & -0.58 & 0.51 & 0.56 & -0.85 & 0.57 & 0.43 \\
\hline Service workers & 0.10 & 0.45 & 1.11 & -0.12 & 0.50 & 0.89 \\
\hline Students not working & 0.30 & 0.48 & 1.35 & 0.21 & 0.54 & 1.24 \\
\hline \multicolumn{7}{|l|}{ Class identity (working class = ref.) } \\
\hline Middle class & -0.08 & 0.25 & 0.93 & 0.05 & 0.27 & 1.05 \\
\hline Other class & 0.18 & 0.55 & 1.20 & 0.35 & 0.59 & 1.42 \\
\hline
\end{tabular}


high degree of unionization among middle-class occupations, although the same general class composition as in the Swedish case can be seen in most of the other surveyed May Day demonstrations presented earlier in the chapter.

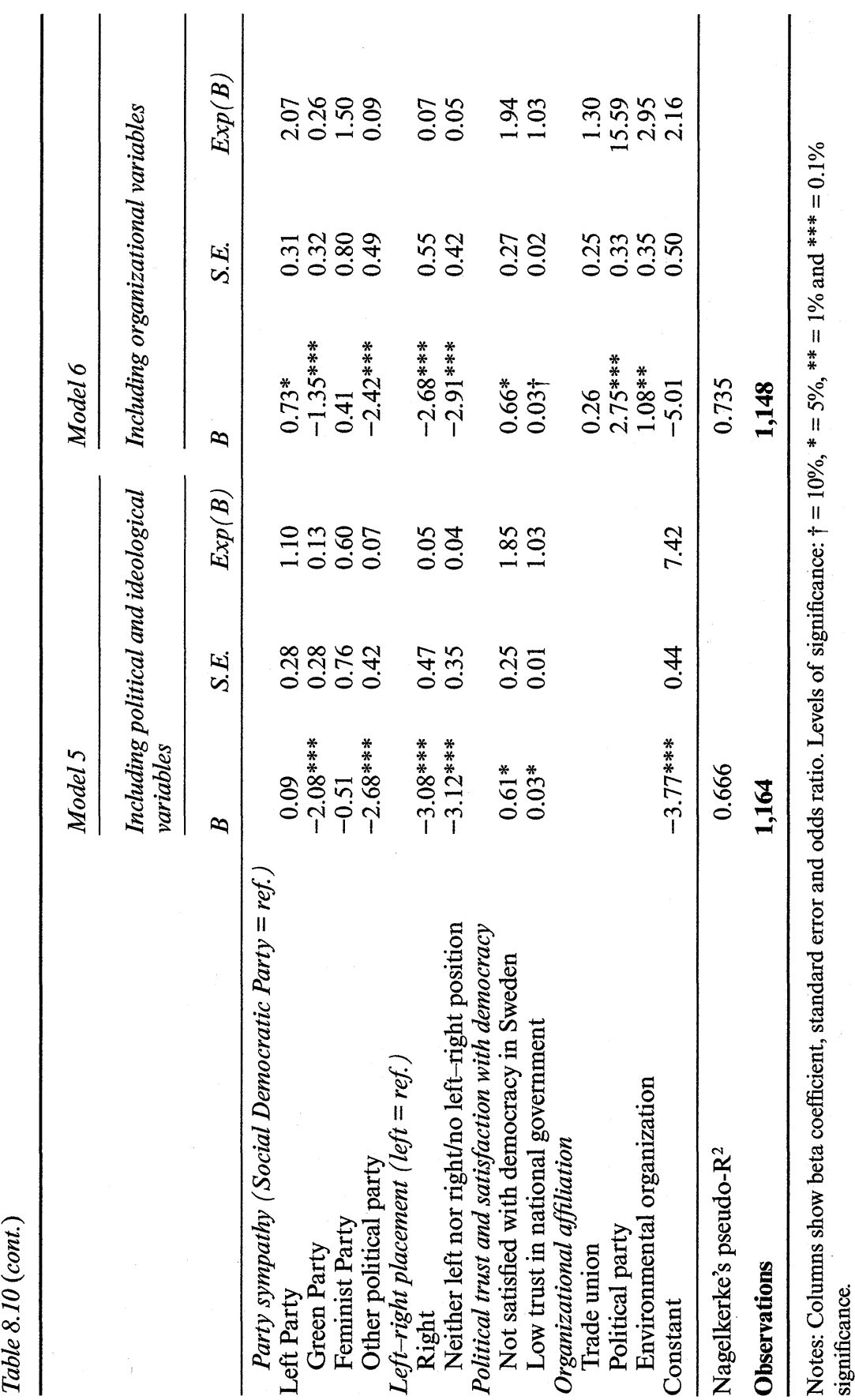

\section{Conclusion}

Although the normalization of street politics has typically been attributed to demonstrations in Western democracies from the 1960s onwards, the history of May Day demonstrations goes back to the late nineteenth century. In this chapter I have examined which socio-demographic groups take part in contemporary May Day demonstrations in order to determine the degree to which the participants in these annual parades reflect the social composition of the general population, and thus confirm the thesis of the social normalization of the protester.

In comparison to the general population, May Day marches attract a larger proportion of the well-educated middle class and a smaller share of the working class. However, in comparison to demonstrations staged by new social movements, May Day parades display a much higher participation of citizens with working-class occupations and a smaller proportion of university-educated participants. Compared to these other types of demonstrations, May Day demonstrations thus stand out as having a social profile that is closer to the general population, even though it is still slanted towards individuals with middle-class occupations.

The more 'normal' or representative social composition is most evident in the May Day parades staged by the major trade union confederations and social democratic parties, while May Day demonstrations arranged by radical left organizations have greater similarities with protests staged by new social movements. On the other hand, with regard to the mobilization of other groups that today also experience a deterioration in social security, e.g. young people, the under- and unemployed, self-employed professionals, these are more present in the May Day demonstrations of the radical left, while the marches staged by the major trade unions and social democratic parties mobilize these groups to a lesser degree. It is thus important to stress that the different types of May Day parades that take place today also tend to mobilize different groups. In the context of austerity policies, a divide can be observed in how two groups that are both negatively affected by the economic crisis and its aftermath, namely the traditional working class and the group excluded from social security that is now often referred to as 'the precariat', are mobilized through different channels. This division also shows that it is important to acknowledge that contemporary May Day demonstrations fall back on different traditions within the labour movement and on different types of primary constituencies.

Class still matters for May Day participation, albeit in perhaps less predictable ways. Even though individuals with working-class occupations are more inclined to take part in May Day demonstrations than those from most other 
occupational classes, the group that is most predisposed to demonstrate on May Day belongs to the occupational middle class: socio-cultural professionals and semi-professionals. This indicates that among today's wage-labourers, it is not only individuals with traditional working-class occupations that take to the streets to protest against social injustices, but also other employees and professionals belonging to specific parts of the occupational middle classes (cf. Kriesi 1989). Apparently, May Day is not just a working-class affair, since today we can see other classes mobilized by the labour movement's calls for social justice. This seems to illustrate the changing conditions for political mobilizations in a Europe in which austerity policies of later years have not only undermined the social rights and opportunities of the working class but also for groups traditionally belonging to the middle class.

Despite the fact that my analysis has shown that class still matters for May Day participation, it has also revealed that other factors are even stronger predictors for individuals' participation in May Day marches, in particular their ideological convictions and political attitudes. These aspects are analysed in greater detail in the following chapter, which examines individuals' motives for participating in May Day demonstrations.

\section{Notes}

1 The question of who really took part in the first May Day parades is difficult to answer, because no protest surveys were conducted when these took place. Comparisons with today's situation are also difficult, given that the class composition of most European societies has changed drastically since the late nineteenth and early twentieth century, particularly with the expansion of the middle class. At the same time, it should be remembered also that during the first decades of the twentieth century social democratic parties in Europe drew extensive electoral support from the middle class (see e.g. Sperber 1997, p. 63ff.) and did not attract only working-class voters. It thus seems plausible that already early on the same parties attracted individuals from the middle class to the May Day parades.

2 The ESS5 covers the countries included in the CCC data used in this chapter, except for Italy, which did not take part in this round of the European Social Survey.

3 Here I would especially like to thank Anders Hylmö for manually classifying the occupation of all cases in the CCC dataset, as well as managing all the coding of the data into Oesch's class categories.

4 According to OECD (2013), in 2011 the percentages of foreign-born in the countries in our study were as follows: Belgium 15 per cent; Italy 9 per cent; Spain 15 per cent; Sweden 15 per cent; Switzerland 27 per cent; and the UK 12 per cent.

5 This type of regression plots so-called odds ratios for each factor (in the table labelled $\operatorname{Exp}(B))$, i.e. a figure for how the probability of having a specific quality (here, identifying as working or middle class) is affected by other individual characteristics (e.g. gender) when the effects of many variables analysed simultaneously are considered.

\section{References}

Andretta, M., and Reiter, H. (2009). Parties, unions, and movements: The European left and the ESF. In D. della Porta (Ed.), Another Europe: Conceptions and
Practices of Democracy in the European Social Forums (pp. 173-203). London: Routledge.

Cigéhn, G., and Johansson, M. (1997). Klassidentitet $i$ upplösning? Om betydelsen av klass, politik och arbete $i$ 90-talets Sverige. Umeå: Umeå universitet.

Cigéhn, G., Johansson, M., and Karlsson, L. (2001). Klassamhällets återkomst: Om klassidentitet, arbetsliv och fritid vid tröskeln till ett nytt sekel. Umeå Studies in Sociology. Umeå: Umeå University.

Crompton, R. (2010). Class and employment. Work, Employment and Society, 24(1), 9-26.

Eder, K. (1995). Does social class matter in the study of social movements?: A theory of middle-class radicalism. In L. Maheu (Ed.), Social Movements and Social Classes: The Future of Collective Action (pp. 21-54). London: Sage.

Goldthorpe, J. (2000). On Sociology: Numbers, Narratives, and the Integration of Research and Theory. Oxford: Oxford University Press.

Hylmö, A., and Wennerhag, M. (2015). Does class matter in anti-austerity protests? Social class, attitudes towards inequality, and political trust in European demonstrations in a time of economic crisis. In M. Giugni and M. Grasso (Eds) Austerity and Protest: Popular Contention in Times of Economic Crisis. Farnham, UK: Ashgate.

Klandermans, B. (2004). The demand and supply of participation: Social-psychological correlates of participation in social movements. In D.A. Snow, S.A. Soule and H. Kriesi (Eds) The Blackwell Companion to Social Movements (pp. 360-379). Malden, MA: Blackwell.

Kriesi, H. (1989). New social movements and the new class in the Netherlands. American Journal of Sociology, 94(5), 1078-1116.

March, A., and Kaase, M. (1979). Background of political action. In S.H. Barnes, and M. Kaase (Eds), Political Action: Mass Participation in Five Western Democracies (pp. 97-136). London: Sage.

March, L. (2011). Radical Left Parties in Europe. London: Routledge.

Morales, L. (2011). Conceptualising and measuring migrants' political inclusion. In L. Morales, and M. Giugni (Eds) Social Capital, Political Participation and Migration in Europe: Making Multicultural Democracy Work? (pp. 19-42). Basingstoke, UK: Palgrave Macmillan.

Norris, P. (2002). Democratic Phoenix: Reinventing Political Activism. New York: Cambridge University Press.

Norris, P., Walgrave, S., and Van Aelst, P. (2005). Who demonstrates? Antistate rebels, conventional participants, or everyone? Comparative Politics, 37(2), 189-205.

OECD. (2013). International Migration Outlook 2013. Paris: Organisation for Economic Cooperation and Development.

Oesch, D. (2006a). Redrawing the Class Map: Stratification and Institutions in Britain, Germany, Sweden, and Switzerland. New York: Palgrave Macmillan.

Oesch, D. (2006b). Coming to grips with a changing class structure: An analysis of employment stratification in Britain, Germany, Sweden and Switzerland. International Sociology, 21(2), 263-288.

Oesch, D. (2008a). The changing shape of class voting. European Societies, 10(3), 329-355.

Oesch, D. (2008b). Explaining workers' support for right-wing populist parties in Western Europe: Evidence from Austria, Belgium, France, Norway, and Switzerland. International Political Science Review, 29(3), 349-373. 
Peterson, A., Wahlström, M., and Wennerhag, M. (2012). Swedish trade unionism: A renewed social movement? Economic and Industrial Democracy, 33(4), 621-647.

Sperber, J. (1997). The Kaiser's Voters: Electors and Elections in Imperial Germany. Cambridge: Cambridge University Press.

Standing, G. (2011). The Precariat: The New Dangerous Class. London: Bloomsbury Academic.

Waterman, P. (2001). Trade union internationalism in the age of Seattle. Antipode: A Radical Journal of Geography, 3, 315-336.

Weber, M. (1922/1978). Economy and Society: An Outline of Interpretive Sociology, vol. 2. Berkeley: University of California Press.

Van Aelst, P., and Walgrave, S. (2001). Who is that (wo)man in the street? From the normalisation of protest to the normalisation of the protester. European Journal of Political Research, 39(4), 461-486.

Verba, S., Schlozman, K.L., and Brady, H.E. (1995). Voice and Equality: Civic Voluntarism in American Politics. Cambridge, MA: Harvard University Press.

Wright, E.O. (2009). Understanding class: Towards an integrated analytical approach. New Left Review, 60, 101-116. 